\title{
Breast cancer survival in Great Cuiaba, Brazil: a population-based study
}

\author{
Sobrevida para o câncer de mama na grande Cuiabá, Brasil: \\ estudo de base populacional \\ Supervivencia para el cáncer de mama en el Gran Cuiabá, Brasil: \\ estudio poblacional \\ Jânia Cristiane de Souza Oliveira ${ }^{a}$ \\ Noemi Dreyer Galvão ${ }^{b}$ \\ Marcelino Alves Rosa de Páscoa ${ }^{c}$ \\ Elicleia Filgueira Santiago de Azevedo ${ }^{d}$ \\ Ageo Mário Cândido da Silvab
}

\section{How to cite this article:}

Oliveira JCS, Galvão ND, Páscoa MAR, Azevedo EFS, Silva AMC. Breast cancer survival in Great Cuiaba, Brazil: a population-based study. Rev Gaúcha Enferm. 2021;42:e20190509. doi: https://doi. org/10.1590/1983-1447.2021.20190509
'Universidade Federal de Rondonópolis (UFR), Instituto de Ciências Exatas e Naturais, Curso de Graduação em Enfermagem. Rondonópolis, Mato Grosso, Brasil.

Universidade Federal de Mato Grosso (UFMT) Instituto de Saúde Coletiva, Departamento de Saúde Coletiva. Cuiabá, Mato Grosso, Brasil.

Universidade Federal de Mato Grosso (UFMT), Instituto de Ciências Exatas e da Terra, Departamento de Estatística. Cuiabá, Mato Grosso, Brasil.

¿ Unimed Cuiabá, Atenção Primária e Suplementar. Cuiabá, Mato Grosso, Brasil.

\section{ABSTRACT}

Objective: To analyze ten-year specific survival of women with breast cancer in Great Cuiaba, Mato Grosso, Brazil.

Methods: A population-based cohort of 61 women diagnosed with breast cancer in 2008 and 2009, in Great Cuiabá, Mato Grosso, followed by 2018 in the regional mortality database. Specific survival was analyzed through the Kaplan-Meier curve, with adjustment of the Weibull model and Log-Weibull Regression. The survival curves of the variables were compared using the log-rank test which were statistically significance $(p<0.05)$.

Results: The mean time to death is approximately 51.1 months. Women aged $\leq 50$ years and of white race/color presented the worst survival.

Conclusion: We found out that age, race/color affect specific survival and there is a need for reviewing the control plan for breast cancer in order to increase the survival of women diagnosed with this pathology.

Keywords: Women's health. Breast neoplasms. Survival analysis. Information systems.

\section{RESUMO}

Objetivo: Analisar a sobrevida específica em 10 anos para o câncer de mama feminino na Grande Cuiabá, Mato Grosso, Brasil. Métodos: Coorte de base populacional composta por 61 mulheres diagnosticadas com câncer de mama, período 2008-2009, na Grande Cuiabá, Mato Grosso, seguidas até 2018 no banco de mortalidade regional. A sobrevida foi analisada por meio das curvas de Kaplan-Meier, com ajuste do modelo Weibull e Regressão Log-Weibull. Compararam-se as curvas de sobrevida por meio do teste log-rank e as diferenças estatísticas foram significantes com $p<0,05$.

Resultados: 0 tempo médio até a morte por câncer de mama foi de aproximadamente 51,1 meses. Apresentaram pior sobrevida as mulheres com idade $\leq 50$ anos e raça/cor branca.

Conclusão: Evidenciou-se que a idade e a raça/cor afetaram a sobrevida específica para este câncer. Há necessidade de revisão da política oncológica do estado para aumentar a sobrevida das mulheres com essa patologia.

Palavras-chave: Saúde da mulher. Neoplasias da mama. Análise de sobrevida. Sistemas de informação.

\section{RESUMEN}

Objetivo: Analizar la supervivencia específica en 10 años de las mujeres con cáncer de mama en el Gran Cuiabá, Mato Grosso, Brasil. Método: Cohorte poblacional de 61 mujeres diagnosticadas con cáncer de mama en los años de 2008 y 2009, en el Gran Cuiabá, Mato Grosso, seguidas hasta 2018 en el banco regional de mortalidad. La supervivencia específica se analizó utilizando curvas de Kaplan-Meier, con ajuste del modelo Weibull y Regresión Log-Weibull. Las curvas de supervivencia de las variables que fueron estadísticamente significativas $(p<0.05)$ se compararon mediante la prueba de log-rank.

Resultados: El tiempo promedio hasta la muerte es de aproximadamente 51.1 meses. Las mujeres de $\leq 50$ años y de raza/blanca presentaron peor supervivencia.

Conclusión: Descubrimos que la edad y la raza/color afectan la supervivencia específica y que es necesario revisar el Plan de control del cáncer de mama para aumentar la supervivencia de las mujeres diagnosticadas con esta enfermedad.

Palabras chave: Salud de la mujer. Neoplasias de la mama. Análisis de supervivencia. Sistemas de información. 


\section{口INTRODUCTION}

Breast cancer is the most prevalent cancer in the female population. In 2018, it represented $24.2 \%$ of total cancers in women worldwide with approximately 2.1 million cases, being the fifth leading cause of cancer deaths worldwide, considering both sexes ${ }^{(1)}$.

In Brazil, breast cancer is the most prevalent in women in all regions of the country. In 2019, an adjusted incidence rate of 56.33 cases per 100,000 women ${ }^{(2)}$ and adjusted mortality rate of 13.0 per 100,000 women ${ }^{(1)}$ was estimated.

In our country, the breast cancer mortality rate has an upward curve, adjusted by the world population, and represents the leading cause of deaths by cancer in the female population, with 12.73 deaths/100,000 women in 2016 and 13.22 in 2017. It was no different in the midwest region; the mortality rate was 12.18 deaths $/ 100,000$ women in 2016, and 13.54 in 2017. In Mato Grosso, the rate was 11.72 deaths/100,000 women in 2016, and 13.38 in 2017, while in Cuiabá, it was approximately twice as much, with 21.34 deaths/100,000 women in 2016, and 22.14 in $2017^{(3)}$. Perhaps this disparity is due to the difficult access to cancer diagnostics and treatment services for those who live in the countryside, since the state's oncology reference service is located in the capital.

Survival analysis studies assess the influence of individual characteristics and disease on a person's likelihood of surviving until a specified period. This type of analysis, such as that performed using Population-Based Cancer Registries (RCBP), takes into account the time between the disease diagnosis date until the person's death ${ }^{(4)}$.

The importance of the survival analysis technique is that, when using a population-based database, this type of study can be used in average disease prognosis studies in a given population and provide objective assessments of the effectiveness of applied cancer therapy in that region ${ }^{(4)}$.

There has been an increase in studies of survival analysis worldwide in recent years due to the relevance of this subject, including in Brazil. However, when searching for studies on the subject in the central-west region, especially in Mato Grosso, there was a lack there of.

Another factor is that, despite breast cancer being one of the priorities of the Oncology Care Action Plan in the State of Mato Grosso, which includes cancer control strategies such as investment in screening, there is still a high mortality rate for the disease. Thus, in addition to granting visibility to the magnitude of breast cancer, the study will provide subsidies to propose effective actions to control the disease ${ }^{(5)}$.

The research question was developed taking into account the relationship between survival analysis and the magnitude of the disease, with the following result: what is the estimated survival rate for breast cancer in Greater Cuiabá, cohort from 2008 to 2009? What interferes in the survival of this population with breast cancer?

To this end, the objective of the study was to analyze the specific 10-year survival of women with breast cancer, in the cohort of 2008 and 2009, from the population base of Greater Cuiabá, Mato Grosso, Midwest region of Brazil.

\section{METHODS}

Population-based, non-concurrent cohort study, consisting of new cases of women diagnosed with breast cancer in the Population-Based Cancer Registry (RCBP) of Greater Cuiabá, comprising the municipalities of Cuiabá and Várzea Grande, state of Mato Grosso, Brazil. The study included women diagnosed from January 2008 to December 2009, passively monitored in the regional Mortality Information System (SIM), until December 2018. In situ cases of breast cancer were excluded.

Prior to pairing the databases, the SIM database was cleaned, excluding cases whose cause of death was "blank", or was listed as "unknown" or ignored. Then, columns that would not be used in both databases were excluded, namely: patient code, name of RCBP, name of source, medical record, patient's personal documents, nationality, place of birth, profession, address, origin, patient exam number, indicator of a rare case. In the RCBP database, only incidental cases were selected (definitive indicator "true"). In the records of the RCBP database with no information in the field "mother's name" and/or "date of birth", a survey was carried out in the User Registration System of the Unified Health System (CADSUS), which also allowed the data to be paired.

Then, the three probabilistic linkage processe ${ }^{(6)}$ began: standardization, a stage in which nominal prepositions, such as "da", were eliminated on the basis of SIM, to become similar to the RCBP database. In addition, the writing of the gender "Female", "Male" was standardized due to its relevance. this information was used for blocking, which was the second stage of the process. The third step was pairing, in which scores are constructed to indicate the degree of agreement between records of the same pair through a blocking strategy.

From the probabilistic relationship between the databases, 92 pairs were found, all true. Two (02) records from that sample were excluded from the database because their municipality of residence is not covered by the RCBP Cuiabá (Juína and Sorriso). In 29 other records, the information available was restricted to death certificate, with no follow-up over the years. These cases were also excluded from the database. Thus, a total of 61 women were observed in the study. 
The dependent variable was the time at which people entered the study (date of diagnosis for breast cancer) until death from the disease. Studies like this are called survival analysis ${ }^{(7)}$. The analyzed outcome was the time between the breast cancer diagnosis in women, until death from the disease, called specific survival(8).

The following covariables were analyzed: time from diagnosis of breast cancer to death from the disease (in months); age ( $\leq 50$ years and $>50$ years); race/color (white, not white); marital status (married and not married); education ( $<8$ years and $\geq 8$ years of education); municipality (Cuiabá, Várzea Grande); diagnostic means (primary tumor histology, others) and morphology (infiltrating ductal carcinoma, others). The other clinical and pathological variables that appear in the RCBP Tumor Record Form were not analyzed because, for the analyzed period, they presented incompleteness of $70 \%$ or more, such as: tumor laterality, extension and staging.

In Brazil, the race/color variable is defined by the color of the skin and considered self-reported, meaning that the person who defines his/her race/color, without interference from the interviewer/researcher. We chose to follow the racecolor categorization variable according to the Brazilian Institute of Geography and Statistics ${ }^{(9)}$. To assemble the database, the variable race/color of the RCBP database (self-reported) was used, categorized as "white" and, the others, "non-white" (black, brown, yellow and indigenous). However, when there was no information for this variable in the RCBP database, information from the SIM database was used.

Exploratory data analysis was initially used to ascertain the variable's behavior. The Weibull model was adjusted to the time of the diagnosis to death from breast cancer. The estimates of the model parameters were obtained using the Maximum Likelihood Method. Weibull estimates were compared with the Kaplan-Meier nonparametric estimate. The Log-Weibull regression model was adjusted using the Maximum Likelihood Method to test the effect of independent variables (covariates) in a study on the time between diagnosis to death from breast cancer. The survival curves of the variables that showed statistical significance $(p<0.05)$ were compared using the log-rank test ${ }^{(7)}$.

Parametric modeling of Survival Analysis was used in this study, because this type of analysis presumes that the time t until the event of interest follows a known probability distribution and the corresponding parameters are estimated. The distribution that showed the best fit was Weibull , not coincidentally the most used in the health area, since it is based on the assumption that the risk does not vary linearly with time $e^{(7)}$.
The probabilistic linkage was performed using the Link Plus software version 2.0, and the survival analysis using the R software ${ }^{(10)}$.

The study meets the precepts of Resolution No. 466/2012 of the National Health Council, as it is part of the matrix project entitled "Cancer and its associated factors: analysis of population and hospital base records in Cuiabá-MT" ("Câncer e seus fatores associados: análise de registro base populacional e hospitalar de (uiabá-MT"), approved by the Ethics Committee of the Júlio Muller Hospital under CAAE number: 98150718.1.0000.8124.

\section{RESULTS}

Sixty-one (61) women were included in the analyzed cohort. The time from diagnosis to death from breast cancer varied between 5 and 120 months, with an average time until death of approximately 51.1 months. It was also shown that $50 \%$ of women died shortly after completing four years of diagnosis of the disease.

As for the sociodemographic characteristics of women with breast cancer, it was observed that the average age of the women in the study was 59 years old and that 43 (70.49\%) were over 50 years old; 35 (60.34\%) were non-white; 37 (47.59\%) had less than 8 years of education and 47 (77.05\%) lived in the city of Cuiabá. As for the clinical characteristics, 60 (98.37\%) were diagnosed through histology of the primary tumor and 46 (75.41\%) were diagnosed through infiltrating ductal carcinoma morphology (Table 1).

The chart reflecting the total time in test (TTT curve), proposed by Aarset ${ }^{(11)}$, was constructed for the breast cancer data set, as shown in Figure 1, indicating an increasing risk function. Thus, the Weibull distribution was adequate to analyze this data set.

The maximum likelihood estimates of each parameter with the respective standard errors (in parentheses) from adjusting the Weibull model to the time of diagnosis to death from breast cancer were $a=57.6314$ (4.0486) and $\tau$ $=1.9169$ (0.1953).

Figure 1 also showed the comparison of the estimate according to the Weibull model, with the Kaplan-Meier non-parametric estimate. It was observed by the figure that the Weibull distribution gave us a satisfactory fit for the breast cancer data. The estimated density of the breast cancer data model was also evidenced. The Weibull model concluded that the probability of a woman dying by the fifth year after diagnosis is $66.04 \%$, the average time from diagnosis to death was 51.13 months, after surviving five years the women had a $3.45 \%$ risk of dying, with an accumulated risk of $108.02 \%$ of dying in the fifth year after diagnosis. 
Table 1 - Sociodemographic and clinical characteristics of women with breast cancer ( $n=61)$, Cuiabá and Várzea Grande/ MT, 2008 to 2009

\section{Variable}

Absolute frequency (n)

Relative frequency (\%)

Age
$\leq 50$ years old
18
29.51
$>50$ years old
43
70.49

Race / color

White

Not white

60.66

Marital status

Married

39.34

Not married

60.66

Education

$<8$ of schooling

$\geq 8$ of schooling

Municipality

Cuiabá

Varzea Grande

Half diagnosis

Primary tumor histology

Other

Morphology

Infiltrating ductal carcinoma

Other

The Log-Weibull regression model was adjusted. Table 2 shows the maximum likelihood estimates (MLEs) for the parameters of the Log-Weibull regression model, adjusted to the breast cancer data, using the R software optim package. The explanatory variables Age and Race/color were marginally significant for the Log-Weibull regression model at the 5\% significance level. Thus, the disease affected women regardless of education, marital status and means of diagnosis, for the data analyzed.
The Log-Weibull regression model was adjusted again, removing the variables that lacked statistical significance. Table 2 shows the MLEs for the Log-Weibull regression model parameters, adjusted to the breast cancer data. According to the final model (Table 3), it was observed that women over the age of 50 have a 35.79\% higher survival rate than women under the age of 50 and nonwhite women have a $73.66 \%$ higher survival rate than white women. 

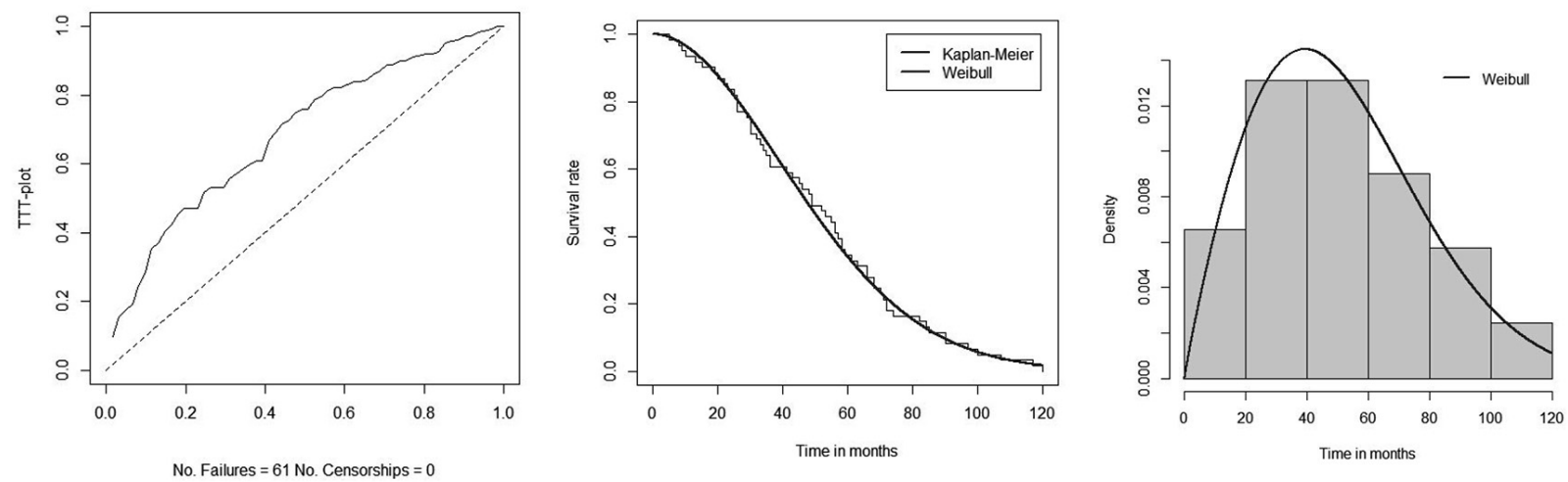

Figure 1 - TTT curve for breast cancer data. Estimates of the survival function according to Kaplan-Meier and Weibull model for data on breast cancer and estimated density of the analyzed model. Cuiabá and Várzea Grande/MT, 2008 to 2009 Source: Research data, 2019.

Table 2 - Parameter estimates, standard errors, $p$ - value and 95\% confidence intervals for the Log-Weibul model, adjusted to the breast cancer data. Cuiabá and Várzea Grande/MT, 2008 to 2009

\begin{tabular}{lcccc} 
Parameter & Estimate & Standard error & P value & Cl 95\% \\
$\sigma$ & 0.4509 & 0.0473 & $<0,0001$ & $(0.3672 ; 0.5538)$ \\
Intercept & 4.4059 & 0.4884 & $<0,0001$ & $(3.4486 ; 5.3632)$ \\
Age & 0.2883 & 0.1345 & $\mathbf{0 . 0 0 3 2}$ & $(0.0247 ; 0.5519)$ \\
Education & -0.0078 & 0.0297 & 0.7928 & $(-0.0660 ; 0.0504)$ \\
Race / color & -0.2979 & 0.1248 & $\mathbf{0 . 0 1 7 0}$ & $(-0.5424 ;-0.0533)$ \\
Marital status & -0.1116 & 0.1191 & 0.3485 & $(-0.3450 ; 0.1218)$ \\
Means of diagnosis & -0.3968 & 0.4607 & 0.3890 & $(-1.2997 ; 0.5060)$ \\
\hline
\end{tabular}

Source: Research data, 2019.

Table 3 - Parameter estimates, standard errors, $p$ - value and 95\% confidence intervals for the Log-Weibul model, adjusted to the breast cancer data, excluding covariates that were not significant. Cuiabá and Várzea Grande/MT, 2008 to 2009

\begin{tabular}{lcccc} 
Parameter & Estimate & Standard error & P value & $\mathbf{C l = 9 5 \%}$ \\
$\sigma$ & 0.4585 & 0.0479 & $<0.0001$ & $(0.3736 ; 0.5627)$ \\
Intercept & 3.9334 & 0.1365 & $<0.0001$ & $(3.6658 ; 4.2010)$ \\
Age & $\mathbf{0 . 3 0 6 5}$ & 0.1361 & $\mathbf{0 . 0 2 4 3}$ & $(0.0397 ; 0.5732)$ \\
Race / color & $\mathbf{- . 3 0 5 8}$ & 0.1270 & $\mathbf{0 . 0 1 6 1}$ & $(-0.5548 ;-0.0568)$ \\
\hline
\end{tabular}

Source: Research data, 2019 
The comparison of survival curves empirically estimated by the Kaplan-Meier estimator and the Log-Weibull regression model for the variables Age and Race/color for the breast cancer data under study were illustrated in Figure 2. The comparison of survival curves in relation to the variables was performed using the log-rank test, showing that both for the age variable and for the race/color variable, the curves differ from each other.
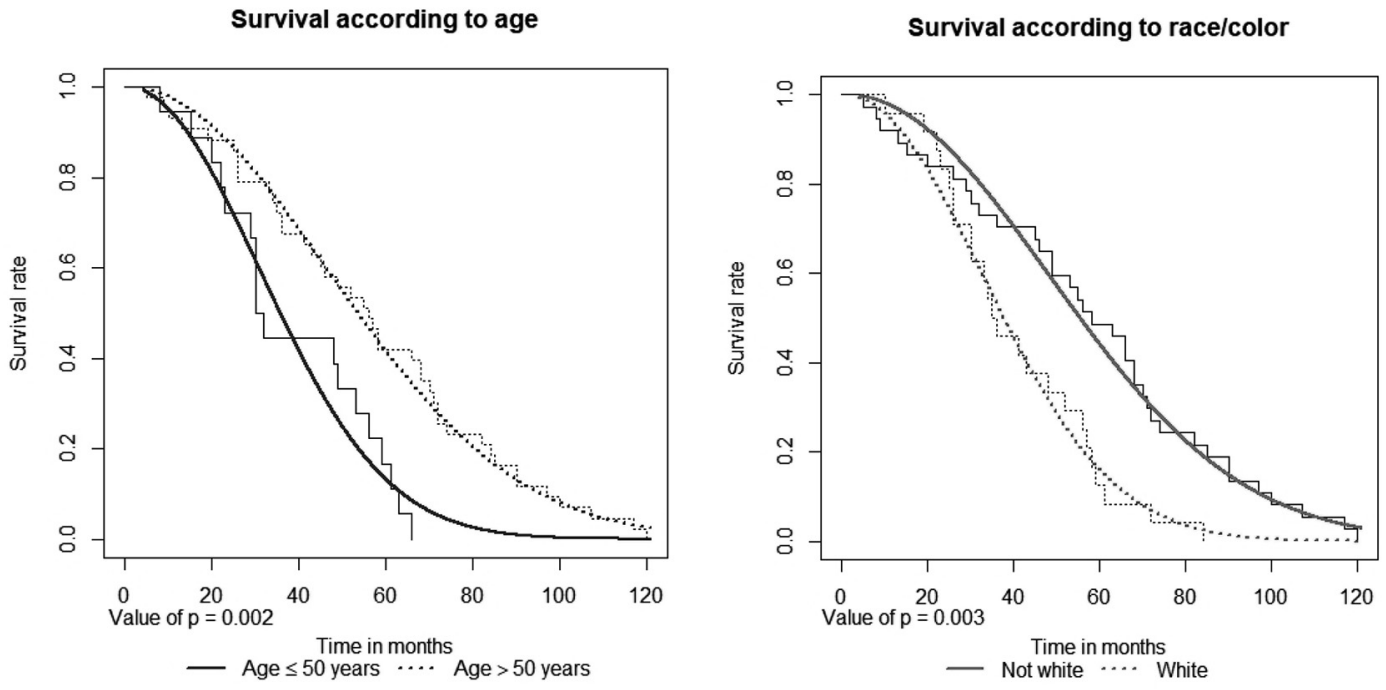

Figure 2 - Ten-year survival of breast cancer according to age and race/color. Cuiabá and Várzea Grande/MT, 2008 to 2009. Source: Research data, 2019.

\section{DISCUSSION}

In this study, that used 61 women diagnosed with breast cancer in the 2008 and 2009 cohort, in the population base of Greater Cuiabá, Mato Grosso, Brazil, it was evidenced that age and race/color showed statistical significance for the analysis of specific survival, with worse survival for women aged $\leq 50$ years and race/color white.

The age finding is consistent with the literature on the survival of women with breast cancer. Several studies ${ }^{(8,12-13)}$ shown a difference in survival among young women and women over 50 years of age.

A population-based study in France ${ }^{(13)}$, showed that the relative survival of women aged $<50$ years was worse than those aged $\geq 50$ years). Young women had a greater chance of being associated with a more aggressive tumor, positive lymph nodes and negative hormonal status, which indicates a worse prognosis of the disease ${ }^{(8)}$.

The worse survival of younger women may reflect late diagnosis, advanced staging, some cases already with lymph node metastasis, negative hormone receptor and positive Her- $2^{(8)}$.

In Brazil, the public health system prioritizes screening in women over the age of 50 and the occurrence of breast cancer in young women is still poorly understood ${ }^{(14)}$. It may be necessary to revise the protocol, insert tests for younger women in an attempt to increase the rate of early diagnosis for this public.

Despite breast cancer being one of the priorities of the Oncology Care Action Plan in the State of Mato Grosso(5), the survival found in the study was low, when compared with other national and international studies ${ }^{(12,15-17)}$. One of the reasons for this finding may be the morphology found in almost $100 \%$ of the women in the study: invasive ductal carcinoma (IDC). According to data in the literature, this is the morphology with the highest incidence in women with breast cancer, invasive ductal carcinoma with no other specification (NOS). Its definition is due to the exclusion of characteristics that qualify it as any of the other subtypes of invasive carcinoma, a classification that comprises the special or specific ones ${ }^{(18)}$.

Invasive ductal carcinoma is a heterogeneous disease. Although $65 \%$ of women with this morphology will not have lymph node metastasis at diagnosis, about $35 \%$ will have a recurrence of the disease and many will die ${ }^{(18)}$. Other aspects can be evaluated to complement the analysis. For example, the presence of metastasis. However, as in the database we used for the study, the incompleteness was high for variables such as staging, it was not possible to analyze whether the women died due specifically to the ICD, or due 
to the diagnosis at a more advanced stage, or associated with some other clinical-pathological factor.

The race/color, in turn, showed a significant association with survival in a way that is contrary to that found in other studies. Perhaps this finding is partly a reflection of the complexity of characterizing this variable due to the relevant racial miscegenation in our country, joined with the individual and visual classification in the categorization of this variable, which may have led to mistakes in its classification.

Several studies have found worse survival for black women, compared to white surviva|(8,17,19). A study conducted in the United States ${ }^{(19)}$, non-Hispanic white women were more likely to have an early diagnosis than African American women.

Studies carried out in Brazil found a higher survival rate for white women compared to non-white women ${ }^{(15-16)}$. A study carried out in Minas Gerais investigated the association between race/color and breast cancer survival. It showed lower survival in women aged less than 50 years or older than 70, race/color black, low income, seen at a public hospital and diagnosed at an advanced stage of the disease. After adjusting for income, the association between race/color and lower survival was attenuated, but still remained significant. In large part, the association between race/color and worse survival, in this study, was due to more advanced staging ${ }^{(15)}$.

In a study carried out in the United States ${ }^{(17)}$, white women, on the other hand, had a survival rate that was 7.4 months longer than black women. The study also showed that the association between income and specific survival for breast cancer depends on race/color, both with and without adjustment of demographic factors, and oncological characteristics of the woman. In contrast to the literature, average income was only associated with survival among white women. The same is true with education. Thus, the study only shows a positive association with socioeconomic status for white women, with no significant change for black women.

Other studies carried out in the United States ${ }^{(12,20)}$, found better survival for white women, when compared to black women. In one of the studies ${ }^{(8)}$, better survival was observed for whites in all age groups analyzed. In the others $^{(12,20)}$, they found greater survival for white women in all periods analyzed.

The complexity of the race/color study reflects the disparity between blacks and whites is due to a complex network of factors interacting with each other, which extrapolate the biological aspect. These factors not only reflect disease staging, tumor characteristics, obesity and comorbidity, but also, or perhaps with greater relevance, access to health services (whether or not they have a health plan or private care), adherence and response to treatment ${ }^{(12)}$. It may also reflect an association with socioeconomic status, with a higher proportion of white women classified in the low poverty demographic, as opposed to black women, with high poverty ${ }^{(8)}$.

Unfortunately, due to the incompleteness of the data in the RCBP database, a limitation of the study was the failure to analyze the association between age and race/color with clinical and pathological characteristics, such as the stage, location and extent of the disease. Uniquely relevant data to the analysis of women's survival and which factors contribute to greater survival.

The complete filling of the RCBP variables is essential for the development of epidemiological studies with in-depth analysis on the theme of cancer. The study of epidemiological variables with those related to diagnosis and treatment increases knowledge about the disease and enables the proposition of policies and work plans aimed at oncological care.

\section{CONCLUSION}

Through the analysis of our study, it was possible to conclude that age and race/color affect the specific survival of women with breast cancer, with worse survival for women aged $\leq 50$ years and race/color white.

Although breast cancer control is a priority in the state cancer plan, its mortality remains high. It is imperative to review the strategies adopted for this control, in addition to monitoring their implementation.

Knowing the factors that worsen the survival of women with breast cancer with population-based data is essential to analyzing whether the measures adopted to control the disease are being effective, and to propose interventions that are actually in accordance with the reality of the scope of each cancer notification center.

\section{$\square$ REFERENCES}

1. International Agency for Research on Cancer (FR) [Internet]. Cancer today. Lyon: IARC, WHO; c2019 [cited 2019 Aug 16]. Available from: https://gco.iarc.fr/ today/

2. Instituto Nacional de Câncer (BR). Estimativa 2018: incidência do câncer no Brasil. Rio de Janeiro: 2017 [cited 2019 Aug 16]. Available from: https:// portaldeboaspraticas.iff.fiocruz.br/wp-content/uploads/2019/10/estimativaincidencia-de-cancer-no-brasil-2018.pdf

3. Instituto Nacional de Câncer (BR) [Internet]. Rio de Janeiro: INCA, c1996-2014 [cited 2019 Nov 09]. Atlas da mortalidade; [about 1 screen]. Available from: http://mortalidade.inca.gov.br/Mortalidade/

4. Parkin DM, Hakulinen T. Análise de sobrevida. In: Registro de câncer: princípios e métodos. Rio de Janeiro: ProOnco; 1995. p.167-84. 
5. Secretaria Estadual de Saúde de Mato Grosso (BR). Resolução Comissão de Intergestores Bipartite/MT Ad Referendum n001 de 20 de fevereiro de 2017. Plano de ação da atenção oncológica no estado de Mato Grosso. Cuiabá: SES/ MT; 2017.

6. Brastulin $R$, Marson PG. Inclusão de etapa de pós-processamento determinístico para 0 aumento de performance do relacionamento (linkage) probabilístico. Cad Saúde Pública. 2018; 34(16):e00088117. doi: https://doi. org/10.1590/0102-311x00088117

7. Carvalho MS, Andreozzi VL, Codeço CT, Campos DP, Barbosa MTS, Shimakura SE. Análise de sobrevivência: teoria e aplicações em saúde. 2. ed. rev ampl. Rio de Janeiro: Editora Fiocruz; 2011.

8. Eng LG, Dawood S, Sopik V, Haaland B, Tan PS, Bhoo-Pathy N, et al. Ten-year survival in women with primary stage IV breast cancer. Breast Cancer Res Treat. 2016;160:145-52. doi: https://doi.org/10.1007/s10549-016-3974-x

9. Instituto Brasileiro de Geografia e Estatística. Manual do recenseador: censo 2010. Rio de Janeiro: IBGE; 2010 [cited 2019 Aug 10]. p.191-3. Available from: https:// biblioteca.ibge.gov.br/visualizacao/instrumentos_de_coleta/doc2601.pdf

10. R Development Core Team. R: a language and environment for statistical computing. Vienna: R Foundation for Statistical Computing; 2018 [cited 2019 Feb 20]. Available from: http://www.R-projetc.org

11. Aarset MV. How to identify bathtub hazard rate. IEEE Trans Rel. 1987;R36(1):106-8.

12. DeSantis CE, Ma J, Sauer AG, Newman LA, Jemal A. Breast cancer statistics, 2017, racial disparity in mortality by state. CA Cancer J Clin. 2017;67(6):439-48. doi: https://doi.org/10.3322/caac.21412

13. Dialla PO, Quipourt V, Gentil J, Marilier S, Poillot ML, Roignot P, et al. In breast cancer, are treatments and survival the same whatever a patient's age? a population-based study over the period 1998-2009. Geriatr Gerontol Int. 2015;15(5):617-26. doi: https://doi.org/10.1111/ggi.12327

14. Rocha-Brischiliari SC, Oliveira RR, Andrade L, Brischiliari A, Gravena AAF, Carvalho MDB, et al. The rise in mortality from breast cancer in young women: trend analysis in Brazil. PLOS ONE. 2017;12(1):e0168950. doi: https://doi. org/10.1371/journal.pone.0168950

\section{- Corresponding author:}

Jânia Cristiane de Souza Oliveira

E-mail: jania@ufr.edu.br
15. Nogueira MC, Guerra MR, Cintra JRD, Correa CSL, Fayer VA, BustamanteTeixeira MT. Disparidade racial na sobrevivência em 10 anos para 0 câncer de mama: uma análise de mediação usando abordagem de respostas potenciais. Cad Saúde Pública. 2018;34(9):e00211717. doi: https://doi. org/10.1590/0102-311X00211717

16. Fayer VA, Guerra MR, Cintra JRD, Bustamante Teixeira MT. Ten-year survival and prognostic factors for breast cancer in the southeast region of Brazil. Rev Bras Epidemiol. 2016;19(4):766-78. doi: https://doi. org/10.1590/1980-5497201600040007

17. Agarwal S, Ying J, Boucher KM, Agarwal JP. The association between socioeconomic factors and breast cancer-specific survival varies by race. PLOS ONE. 2017;12(12):e0187018. doi: https://doi.org/10.1371/journal. pone.0187018

18. Biazus JV, Cavalheio JA, Cericatto R, Zucatto AE, Melo MP. Neoplasia maligna da mama. In: Passos EP, Ramos JGL, Martins-Costa SH, Magalhaes JA, Menke CH, Freitas F, organizadores. Rotinas em ginecologia. 7a ed. Porto Alegre: Artmed, 2017. p. 409-39.

19. Iqbal J, Ginsburg O, Rochon PA, Sun P, Narod SA. Differences in breast cancer stage at diagnosis and cancer-specific survival by race and ethnicity in the United States. JAMA: J Am Med Assoc. 2015;313(2):165-73. doi: https://doi. org/10.1001/jama.2014.17322

20. Lu G, Li J, Wang S, Pu J, Sun H, Wei Z, et al. The fluctuating incidence, improved survival of patients with breast cancer, and disparities by age, race, and socioeconomic status by decade, 1981-2010. Cancer Manag Res. 2018;10:4899914. doi: https://doi.org/10.2147/CMAR.S173099

\section{Acknowledgments:}

To the Mato Grosso State Department for their support in this project.

\section{Associate editor:}

Graziella Badin Aliti

Received: 12.27.2019

Approved: 05.28.2020
Editor-in-chief:

Maria da Graça Oliveira Crossetti 